\title{
Environmental tax as an instrument of economic stimulation to improve the quality of motor fuels
}

\author{
A. Golubeva \& E. Magaril \\ Department of Environmental Economics, \\ Ural Federal University, Russia
}

\begin{abstract}
Carbon dioxide $\left(\mathrm{CO}_{2}\right)$ is a main component of organic fuel combustion, and its increased concentration in the atmosphere causes negative impact assumed to be associated with its contribution into the global climate change. $\mathrm{CO}_{2}$ emission is correlated both with fossil fuel consumption intensification and with toxic substances emissions in the process of fuel combustion, thus indirectly characterizing the general dynamics of pollutants impact upon environment.

Motor transport is one of the major consumers of oil products. Within this context, the search for the ways to reduce $\mathrm{CO}_{2}$ emission from motor vehicles is a priority problem for the global commonwealth.

Taking into account that tax stimulation is one of the most effective instruments of influence on oil-refining companies, an urgent task is to improve the existing tax system to reduce carbon dioxide emissions.

The aim of this work is to substantiate a model and a method to calculate an environmental tax for motor fuel considering not only environmental classes of fuels being used but also the carbon dioxide emissions in the process of their combustion.

The authors have proposed a mechanism for economic stimulation of reduction of carbon dioxide emission from motor transport. A dependence of $\mathrm{CO}_{2}$ emission on motor fuels qualitative characteristics has been disclosed and a methodological approach to calculate the environmental tax for fuel has been found. The proposed methodological approach can be used for improvement of the current system of oil products taxation in order to create incentives for manufacturers of oil products to produce environmentally-friendly fuels.
\end{abstract}


Keywords: $\mathrm{CO}_{2}$ emission, economic stimulation, oil product taxation, motor transport, motor fuel, environmental tax.

\section{Introduction}

The increase in anthropogenic emissions of carbon dioxide $\left(\mathrm{CO}_{2}\right)$ leads to global changes in environmental conditions and reserves of natural resources that create an integrated environmental-economical challenge for contemporary human society. Vehicle fleet currently exceeding one billion of motor cars is one of the main consumers of oil products and, as a consequence, emitters of $\mathrm{CO}_{2}$ in the world. Fuel and energy resources consumption relates to the principal indicators of the civilization development level, and at present the expanding industrial production and global growth of the vehicle fleet are resulting in the increasing rate of the fossil fuel resources depletion. Carbon dioxide emission can be seen as an indicator of oil-related fuels consumption and its reduction is one of the priority problems of sustainable development. However, at present there is no integral mechanism of economic stimulation to reduce $\mathrm{CO}_{2}$ emissions by motor transport. This negatively affects management of negative impact of the emissions and causes ineffectively increased consumption of motor fuels.

Effective application of economic mechanisms stipulated by the Kyoto Protocol is hampered in this case due to the specific character of the greenhouse gases emission inventory for automobiles. At the same time, environmental taxation is a promising tool of economic stimulation within the framework of resources-saving practice and environmental management [1, 2], it is possible to use it in order to establish incentives for reduction of carbon dioxide by motor vehicles.

\section{Mechanism of economic stimulation to reduce $\mathrm{CO}_{2}$ emissions by motor transport}

The implemented analytical research has enabled the authors to propose their scheme for improving the economic stimulation of measures aimed at reduction of $\mathrm{CO}_{2}$ emissions by motor transport (fig. 1).

In specific conditions of different countries of the world the priority directions of motor transport $\mathrm{CO}_{2}$ emissions reduction can differ. In Russia such a direction is the improvement of the quality of produced gasoline and diesel fuels (this would lead to their specific consumption decrease and, consequently to the annual consumption decrease). For a number of countries the priority is the increase of the number of motor vehicles using alternative fuels.

Dynamics of motor fuels consumption by motor vehicles and corresponding dynamics of $\mathrm{CO}_{2}$ emissions, as well as environmental-economical damage associated with the rapid growth of the global vehicle fleet during recent decades demonstrate the necessity of forming an effective mechanism of economic stimulation for motor transport $\mathrm{CO}_{2}$ emission reduction. On the basis of the conducted analytical research the authors propose the mechanism structure shown in fig. 2 . 
Revealing the currently existed and the potential directions

to reduce carbon dioxide emissions by motor transport

\begin{tabular}{|c|}
$\begin{array}{c}\text { Identification of the priority direction of } \mathrm{CO}_{2} \text { emission reduction in } \\
\text { the local conditions (at the country level, interstate level or } \\
\text { for a group of countries) }\end{array}$ \\
\begin{tabular}{|c|} 
Determination of responsible entities in terms of the $\mathrm{CO}_{2}$ emissions \\
by motor transport for the application of the economic stimulation' \\
instruments towards these entities
\end{tabular} \\
Formulation of proposals on the necessity to improve and \\
capplement the existing mechanism of economic stimulating the \\
carbon dioxide emissions reduction \\
Substantiation of a choice of the economic stimulation instruments \\
to affect the entities responsible for $\mathrm{CO}_{2}$ emission by motor \\
transport \\
Improving the currently existing system of oil products taxation as \\
one of the priority instruments of economic stimulation to reduce $\mathrm{CO}_{2}$ \\
emissions by motor transport
\end{tabular}

Figure 1: Scheme of the improvement of economic stimulation to reduce $\mathrm{CO}_{2}$ emissions by motor transport.

Systematization of the main groups of measures on carbon dioxide emission reduction and directions of their implementation carried out by the authors enabled to reveal responsible entities in terms of the $\mathrm{CO}_{2}$ emission by motor transport for the application of the economic stimulation' instruments towards these entities (owners of motor vehicles, car manufacturers, and motor fuel producers), including methods of taxation, in order to get the target outcome, and to differentiate possible instruments of economic stimulating in respect of these responsible entities [1].

\section{Application of taxation instruments for stimulation of reducing carbon dioxide emissions}

The world practice of economic incentives for carbon dioxide emissions reduction possesses an experience of the taxation instruments usage with respect to owners and producers of motor vehicles. The most advanced and efficient system for taxation based on the $\mathrm{CO}_{2}$ emissions by the used cars, with increased fuel consumption, exists in the UK [3], where car owners pay road tax, calculated according to the vehicle environmental class considering carbon dioxide emissions; since March 2011 they have to pay also for the engine capacity [4]. 


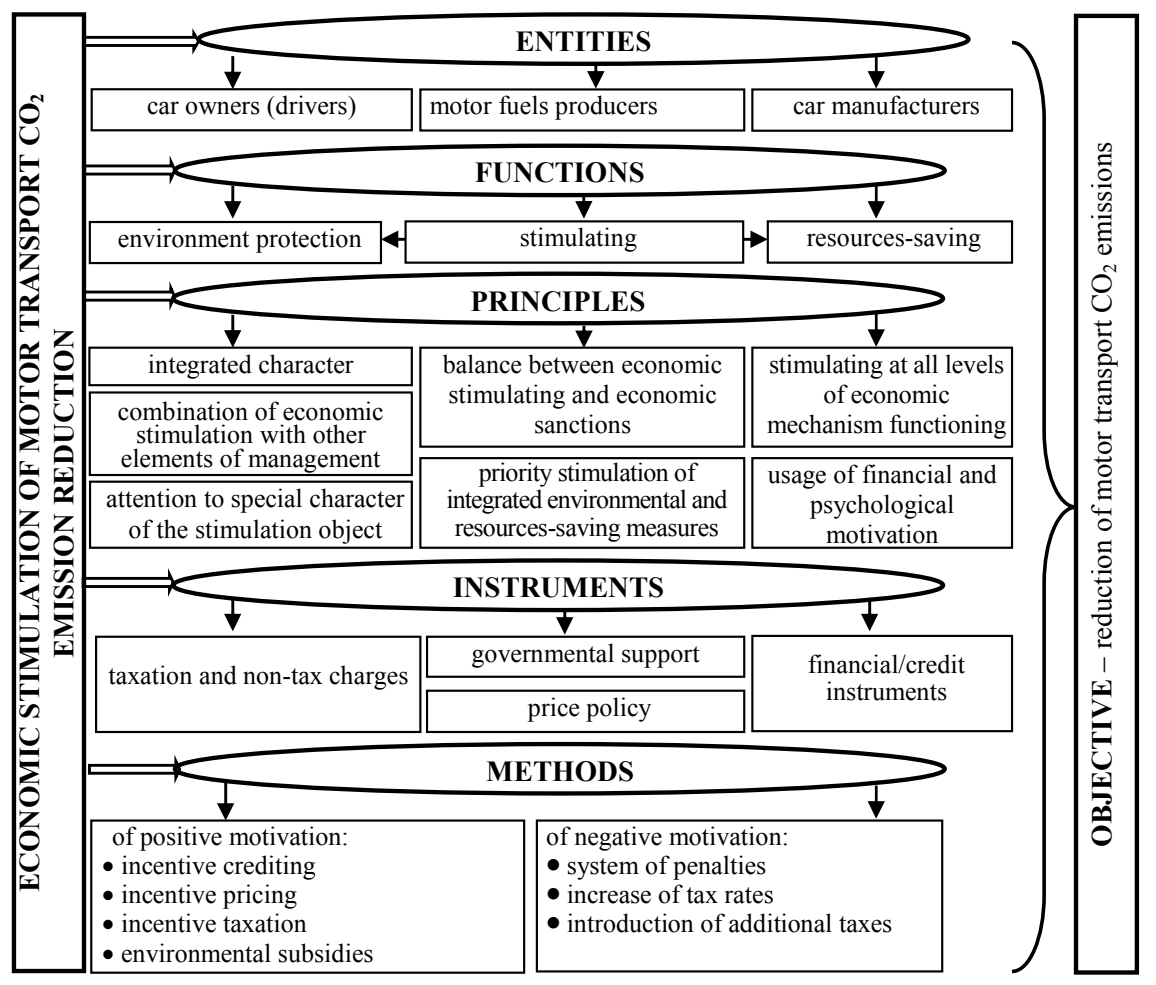

Figure 2: Mechanism of economic stimulation to reduce carbon dioxide emissions by motor transport.

EU Regulation No 443/2009 [5] sets requirements to new cars registered at the EU territory in terms of $\mathrm{CO}_{2}$ specific emission. The Regulation stipulates for certification of motor vehicles in respect of $\mathrm{CO}_{2}$ emissions and charges for exceeding by producers of the permissible volume of $\mathrm{CO}_{2}$ emission.

It should be noted that quality of fuel used in motor transport critically affects the carbon dioxide emissions by vehicles [6-9], this requires special attention to the problem of tax regulation of fuels quality.

Fiscal regulation of oil and gas complex which, on the one hand, should secure a stable increase of the budget income and, on the other hand, should create incentives for investments and techniques of the most advanced world level, is the most significant factor of sustainable economic development of oil industry and as a whole the countries of the world, as well as it is a factor of motor transport sustainable development.

The issue of the improving fuel quality is being solved differently in different countries. The fuel producers in the countries of the first group are taxed extraordinary high (more that the half of retail price of fuel). This group comprises Turkey, as well as France, Germany, Finland - almost the whole of Europe. The other group consists of countries with relatively low taxes for oil 
companies (about 20\%) (USA). Countries of the third group (Ecuador, Nigeria, Malaysia, Bolivia, Indonesia, Syria, Argentina, and countries of the Gulf) act conversely: they grant subsidies from the budget for fuel production thus securing low prices.

The cost of fuel in the USA includes excise, environmental tax, special taxes, and, in addition, local taxes of individual states.

Taxes on fuel vary in different EU member-states but, in general, they include excise (the Netherlands)/tax on fuel (in Germany it depends on environmentfriendly properties of fuel: fuel type, sulfur content, in Sweden it involves tax on carbon and power consumption), tax on road exploitation (Norway), tax on added value, and transport tax [10].

European Union program "20-20-20" stipulating for 20 per cent reduction of carbon dioxide by the EU countries, 20 per cent decrease of their GDP power intensity, and increase of the renewable power sources' share in power balance up to $20 \%$ by $2020[11,12]$, aimed at introduction of two taxes on the power: a tax on $\mathrm{CO}_{2}$ emissions associated with motor fuel combustion for the purposes of heating and a tax on power content in motor and heating fuels that is to replace current taxes and excises charged on physical volumes of energy carriers [11].

Currently acting systems of fuel taxation do not enable to differentiate taxation depending not only on fuel environmental class but also on the $\mathrm{CO}_{2}$ emission amount which can considerably differ within the given quality category.

According to the authors, an environmental tax calculated on the basis of the main tax rate depending on the fuel environmental class and the additional tax rate, which depends on $\mathrm{CO}_{2}$ emission due to the motor fuel combustion, can be an effective instrument of stimulating the fuel quality improvement [1].

In the process of practical implementation of the environmental tax it is necessary to take into account that gas produces considerably less carbon dioxide emission per power unit in comparison with gasoline and diesel fuel, consumption of the gas fuel is to be increased due to its higher environmental properties, considerable available reserves of natural gas, and potential of associated petroleum gas processing. Thus, gas fuels (natural gas (methaneethane) and liquefied gas (propane-butane) are to be exempt from environmental tax.

\section{The model and method of the calculation for the environmental tax on motor fuel}

The authors propose the following universal model for an environmental tax on fuel:

$$
T_{e l_{i j}}=R_{i j} \cdot W_{i j}=\left(R_{m}+R_{a d}\right) \cdot W_{i j},
$$

where $T_{e l_{i j}}$ is the value of environmental tax on the i-th type of fuel (gasoline/diesel fuel) of the $\mathrm{j}$-th environmental class, monetary units; $R_{i j}$ is the 
rate of an environmental tax on motor fuel, monetary units/t; $W_{i j}$ is the weight of the sold $\mathrm{i}$-th type of fuel of the $\mathrm{j}$-th environmental class, $\mathrm{t} ; R_{m}$ is the main rate of the environmental tax on the $\mathrm{i}$-th type of fuel of the $\mathrm{j}$-th environmental class, monetary unit/t, depending on the fuel environmental class; $R_{a d}$ is an additional rate of the environmental tax on the $\mathrm{i}$-th type of fuel, monetary units $/ \mathrm{t}$, to be determined depending on $\mathrm{CO}_{2}$ emission amount in the process of the fuel combustion.

Motor fuel quality and $\mathrm{CO}_{2}$ emission in the process of its combustion to the considerable degree are determined by its density which is an easily measured and controlled indicator of the oil product quality.

Values of relative density, as a rule, are used to characterize fuels (table 1).

Table 1: Density of gasoline and diesel fuel of different categories of quality [13].

\begin{tabular}{|c|c|c|c|c|c|c|}
\hline \multirow{3}{*}{ Indicator } & \multicolumn{3}{|c|}{ Gasoline } & \multicolumn{3}{c|}{ Diesel fuel } \\
\cline { 2 - 7 } & \multicolumn{3}{|c|}{ Quality category } & \multicolumn{3}{c|}{ Quality category } \\
\cline { 2 - 7 } & 1 & 2 & 3 & 1 & 2 & 3 \\
\hline $\begin{array}{c}\text { density at } \\
15^{\circ} \mathrm{C} \\
\mathrm{kg} / \mathrm{m}^{3}\end{array}$ & $715-780$ & $715-770$ & $715-770$ & $820-860$ & $820-850$ & $820-840$ \\
\hline$\rho_{15}^{15}$ & $0.716-0.781$ & $0.716-0.771$ & $0.716-0.771$ & $0.821-0.861$ & $0.821-0.851$ & $0.821-0.841$ \\
\hline
\end{tabular}

Relative density $(\rho)$ is a dimensionless quantity, which value is equal to the ratio of true density of the given substance to the true density of a reference substance taken at the certain temperatures.

It is necessary to note that reduction of the fuel density within the limits of the given category of quality does not require any additional investments and is determined by the temperature range of distillation of gasoline and diesel fractions in the process of petroleum refining $[5,6]$.

Considering the direct linear connection between carbon dioxide emissions and the fuel density [6-9], it is possible to define an additional rate of the environmental tax in accordance with the fuel density.

It should be mentioned that the diesel fuel production is considerably cheaper in comparison with gasoline in terms of oil refining: production of gasoline, besides distillation of crude oil, requires the expensive processes of isomerization with hydrofining, reforming with hydrofining, catalytic cracking with hydrofining, and alkylation. Production of diesel fuel requires only crude oil distillation and hydrofining. Ratio of prices at the oil products market does not correspond to the ratio between production costs and is caused rather by oil companies' gambling with growing demand for diesel fuels. Thus, with taking into account lower cost and higher volume of production, higher $\mathrm{CO}_{2}$ emission both per ton of fuel and per unit of power obtained in the process of fuel combustion, an additional rate of the environmental tax for diesel fuel should be higher than for gasoline [14]. 
To stimulate decrease in density of the motor fuels in production it is expedient to set a zero additional rate for gasoline of minimal density.

When setting the analogical additional rate for diesel fuel it is necessary to take into account: 1) though diesel fuel specific consumption during vehicles' exploitation is less $(25 \%)$ than that of gasoline due to higher effectiveness of diesel engines one had to take into account considerably higher total emissions in case of diesel fuels [7]; 2) in case of the diesel fuel combustion the $\mathrm{CO}_{2}$ emission per power unit is higher than in case of gasoline due to less (in comparison with gasoline) calorific value and higher per cent content of carbon in the fuel; 3) cost of diesel fuel production is substantially lower than that of gasoline. Consequently, the minimal additional rate on diesel fuel is not to be zero and is to be set considering higher carbon dioxide emission in relation to gasoline that has the minimal density.

According to the proposed approach the minimal additional tax rate is to be set for gasoline and diesel fuel with the minimal permissible values of density. In general the formula for the environmental tax additional rate (2), considering the motor fuel density, can be written as follows [1]:

$$
R_{a d}=C_{C_{2}} \cdot\left(W_{C O_{2 i \rho}}-W_{C_{2 i \min \rho}}\right),
$$

where $C_{\mathrm{CO}_{2}}$ is the cost of $\mathrm{CO}_{2}$ emission unit regulated at the state (interstate) level, monetary units/t; $W_{\mathrm{CO}_{2} \rho}$ is $\mathrm{CO}_{2}$ emission caused by combustion of the i-th motor fuel (gasoline/diesel fuel) of the given density sold by the fuel producer, $\mathrm{t} / \mathrm{t} ; W_{C_{2}{ }_{2 i \min \rho}}$ is $\mathrm{CO}_{2}$ emission in case of combustion of the gasoline with minimal density, $\mathrm{t} / \mathrm{t}$.

Total sum of the environmental tax on motor fuels will be:

$$
\begin{aligned}
T_{e l_{i j}}=\sum_{i} \sum_{j} W_{i j} \cdot\left(R_{m}+R_{a d}\right)= & \sum_{i} \sum_{j} W_{i j} \cdot\left(R_{m}+C_{C O_{2}} \cdot\left(W_{C O_{2 i \rho}}-W_{C O_{2 i \min \rho}}\right)\right), \\
\text { monetary units } &
\end{aligned}
$$

where $W_{i j}$ is the fuel weight calculated for transactions recognized as a taxation object over the period to be considered, motor fuel of the i-th type (gasoline/diesel fuel), $\mathrm{j}$-th environmental class, $\mathrm{t}$.

Carbon dioxide formation during fuel combustion $\left(\mathrm{W}_{\mathrm{CO}_{2}}\right)$ depends on the carbon content in it:

$$
W_{\mathrm{CO}_{2}}=0.01 \cdot C \cdot \frac{44}{12}, \text { fuel } \mathrm{t} / \mathrm{t}
$$

where $\mathrm{C}$ is the carbon content in fuel, $\%$.

The carbon content in motor fuel depends on the relative density [7, 14] and is to be determined according Craig formula [7, 14]:

$$
C=74+15 \rho_{15}^{15}, \% \text {, }
$$


where $\rho_{15}^{15}$ is the motor fuel relative density.

Then the dependence of carbon dioxide formation in the process of gasoline and diesel fuel combustion on their density can be calculated:

$$
W_{C O_{2}}=0.01 \cdot\left(74+15 \rho_{15}^{15}\right) \cdot \frac{44}{12}=0.55 \cdot\left(4.93+\rho_{15}^{15}\right), \mathrm{t} / \text { fuel } \mathrm{t}
$$

With taking into account the shown calculated dependencies of $\mathrm{CO}_{2}$ emission on the fuels density and minimal values of the permissible density we obtain the formula for calculating the additional rate of environmental tax:

$$
\begin{gathered}
R_{a d}=C_{C_{2}} \cdot\left(0.55 \cdot\left(4.93+\rho_{15}^{15}\right)-3.105\right)=C_{C_{2}} \cdot\left(0.55 \rho_{15}^{15}-0.394\right), \\
\text { monetary unit/fuel } \mathrm{t}
\end{gathered}
$$

where 3.105 is the carbon dioxide formation in the process of combustion of the gasoline of the minimal permissible density ( $\rho_{15}^{15}=0.716$ ), fuel $\mathrm{t} / \mathrm{t}$.

Taking into account all the above the environmental tax total sum will be:

$$
\begin{gathered}
T_{e l_{i j}}=\sum_{i} \sum_{j} W_{i j} \cdot\left(R_{m}+R_{a d}\right)==\sum_{i} \sum_{j} W_{i j} \cdot\left(R_{m}+C_{C O_{2}} \cdot\left(W_{C O_{2 i \rho}}-W_{C O_{2 i \min \rho}}\right)\right)= \\
=\sum_{i} \sum_{j} W_{i j} \cdot\left(R_{m}+C_{C O_{2}} \cdot\left(0.55 \rho_{15}^{15}-0.394\right)\right), \text { monetary unit }
\end{gathered}
$$

where $W_{i j}$ is the weight of motor fuel of the i-th type (gasoline/diesel fuel), $\mathrm{j}$-the environmental class, $t$, in terms of transactions recognized as a taxation subject over the period under consideration.

For Russia the authors consider the cost of a $\mathrm{CO}_{2}$ emission unit equal to 400 rubles/t (according to [15]). With the use of the proposed formula the dependence of the substantiated environmental tax additional rate on the motor fuel density has been calculated (fig. 3).

Implementation of the proposed environmental tax will create an indicator for oil-refining enterprises in their transition to production of fuels with the decreased density and higher quality category. On the other hand, implementation of the proposed environmental tax that takes into account dependence of $\mathrm{CO}_{2}$ emission on the fuel density and the fuel environmental class will enable to affect economically on the carbon dioxide emission reduction and the fuels quality improvement, this will improve the environmental situation and reduce consumption of scarce motor fuels.

In the all-Russian scale in view of the current annual volumes of fuels production, taken according to [16], the replacement of the fuel excises by the environmental tax can lead, according to authors' estimations, to an increase of the annual tax deductions up to 2.4 billion rubles.

Besides, transition from maximal density motor fuels production to minimal density fuels will enable to reduce $\mathrm{CO}_{2}$ emissions resulting from combustion of gasoline and diesel fuel by 3 million tons, gasoline consumption can be reduced 


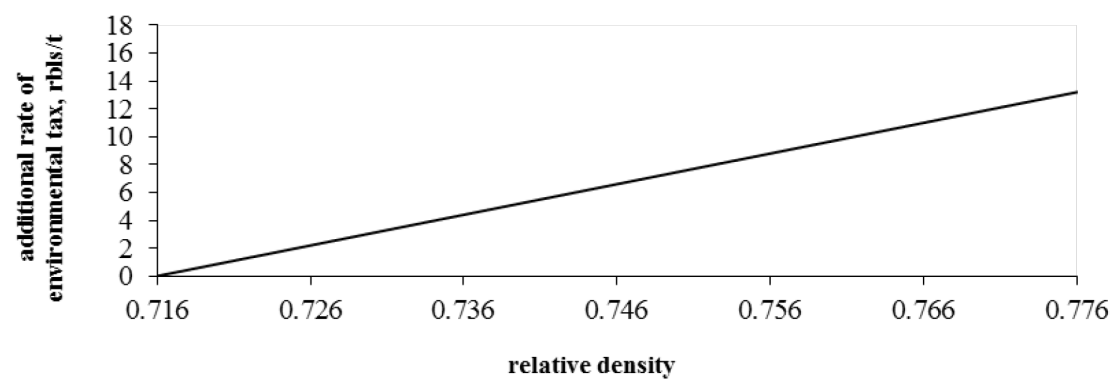

(a)

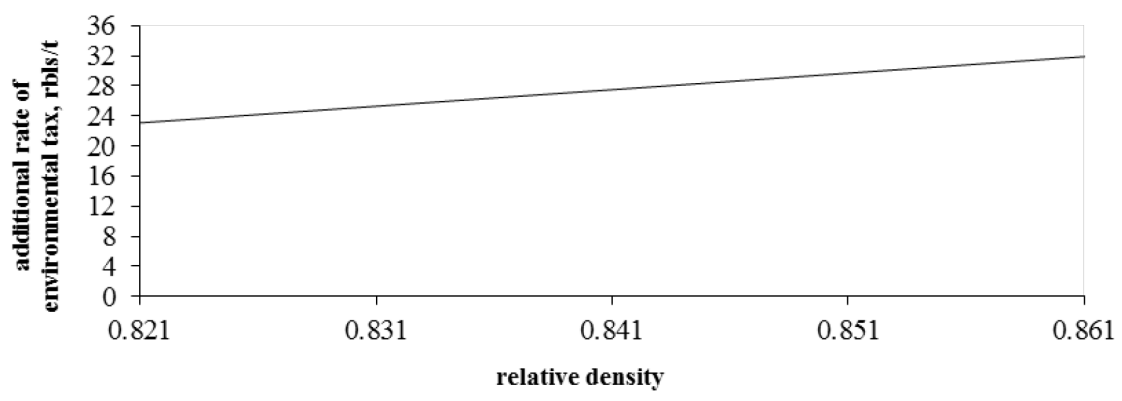

(b)

Figure 3: Dependence of the environmental tax additional rates on the motor fuels density: (a) gasoline; (b) diesel fuel.

by 442 thousand tons, and diesel fuel consumption can be reduced by 532 thousand tons. Assuming the average producers' gasoline price in 2014 was 23 rubles, and diesel fuel price was 22 rubles (according to [17]) the authors estimated the annual economic effect only due to reduction of the motor fuels consumption equal to more than 22 billion rubles.

The authors consider it expedient to apply the principle of non-tax charges for negative impact upon environment with respect to the environmental tax: environmental tax on the minimal density fuels should be paid from production cost of the fuel to be sold, while for the fuels with higher density it should be paid from the profit. The environmental tax on fuels should be paid on the spot of sale (import) of such commodities. It will be useful to distribute the income generated by the environmental tax for two purposes: formation of the road fund (the funds allocated for the roadway covering rehabilitation) and natureprotective measures, in proportions necessary for the problems solution over the given period and the given region in accordance with these purposes.

Such a direction of funds expenditure responds to negative environmental consequences of motor transport use, i.e. wear of roadway covering and emissions of the fuel combustion products including carbon dioxide (and other pollutants: as it was mentioned earlier, total air pollution correlate with $\mathrm{CO}_{2}$ emissions from fuel combustion). 


\section{Conclusion}

Implementation of the environmental tax on motor fuel as an instrument of economic stimulation for the oil resources rational consumption will enable to raise the oil-refining companies' interest to implement measures aimed at improvement of the produced fuel environmental characteristics. This will improve the quality of oil products, will reduce fuels consumption and $\mathrm{CO}_{2}$ emissions by motor transport (at the current state of the vehicle fleet), and will improve the environmental situation in megalopolises.

\section{References}

[1] Golubeva, A. \& Magaril, E., Improved economic stimulation mechanism to reduce vehicle $\mathrm{CO} 2$ emissions. WIT Transactions on the Built Environment, 130, pp. 485-489, 2013.

[2] Mayburov, I. \& Leontieva, Y. Reducing the negative impact of motor transport on the environment: prospects for the use of fiscal instruments in Russia. WIT Transactions on Ecology and the Environment, 186, WIT Press, UK, pp. 863-874, 2014.

[3] Transport tax. World experience, www.miri2.ru/articles/sovety/275.php ?sphrase id=158056.

[4] Lobachev, M. Tax on old age, www.gazeta.ru/auto/2011/10/ 05_a_3790778.shtml.

[5] Regulation (EC) No 443/2009 of the European Parliament and of the Council of 23 April 2009 setting emission performance standards for new passenger cars as part of the Community's integrated approach to reduce $\mathrm{CO} 2$ emissions from light-duty vehicles, http://eur-lex.europa.eu/ LexUriServ/LexUriServ.do?uri=CELEX:32009R0443:EN:NOT.

[6] Magaril, E.R. Influence of the Quality of Engine Fuels on the Operation and Environmental Characteristics of Vehicles: monograph, (in Russian), KDU: Moscow, 2008.

[7] Magaril, E.R., Magaril, R.Z. Motor Fuels (in Russian), Second edition. KDU: Moscow, 2010.

[8] Magaril, E., Magaril, R. Motor Fuels: the Problem of Energy Efficiency and Environmental Safety: monograph, (in Russian), LAP LAMBERT Academic Publishing GmbH\& Co: Saarbrücken, Deutchland, 2012.

[9] Magaril, E. R., The solution to strategic problems in the oil refining industry as a factor for the sustainable development of automobile transport. WIT Transactions on Ecology and the Environment, 190 (2), WIT Press, UK, pp. 821-832, 2014.

[10] Why does not gasoline become cheaper? www.ngfr.ru/article.html?042.

[11] New Power Strategy and the European Union Infrastructure Package, http://mgimo.ru/alleurope/2006/53/article-m-111.html.

[12] Communication from the Commission to the European Parliament, the Council, the European Economic and Social Committee and the Committee of the Regions "Energy 2020. A strategy for competitive, 
sustainable and secure energy". Brussels, 10.11.2010 COM (2010) 639 final. http://eur-lex.europa.eu/legal-content/EN/TXT/?uri=CELEX: 52010 DC0639.

[13] Worldwide Fuel Charter, Fifth Edition, September 2013. http://www.acea.be/uploads/publications/Worldwide_Fuel_Charter_5ed_2 013.pdf.

[14] Magaril, E., Improving car environmental and operational characteristics using a multifunctional fuel additive. WIT Transactions on Ecology and the Environment, 147, WIT Press: UK, pp. 373-384, 2011.

[15] The Russian Federation State Program "Power effectiveness of development of power sector", http://minenergo.gov.ru/upload/iblock/ afc/afc90b96ec0fef29f2ededabb6a4a131.pdf.

[16] Information Telegraph Agency of Russia, ITAR-TASS, http://itar-tass .com/ekonomika/1683817.

[17] Federal state statistics service, http://www.gks.ru. 